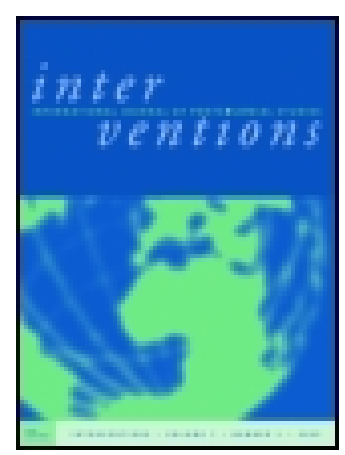

Interventions

International Journal of Postcolonial Studies

ISSN: (Print) (Online) Journal homepage: https://www.tandfonline.com/loi/riij20

\title{
Lotus and the Self-Representation of Afro-Asian Writers as the Vanguard of Modernity
}

\section{Zeyad el Nabolsy}

To cite this article: Zeyad el Nabolsy (2020): Lotus and the Self-Representation of Afro-Asian Writers as the Vanguard of Modernity, Interventions, DOI: 10.1080/1369801X.2020.1784021

To link to this article: https://doi.org/10.1080/1369801X.2020.1784021

$$
\text { 册 Published online: 24 Jun } 2020 .
$$

Submit your article to this journal $\square$

Q View related articles $\longleftarrow$

View Crossmark data ¿ 


\title{
LOTUS AND THE SELF-REPRESENTATION OF AFRO-ASIAN WRITERS AS THE VANGUARD OF MODERNITY
}

\section{Zeyad el Nabolsy}

Africana Studies and Research Center, Cornell University, USA

\begin{abstract}
This essay has two aims. The first is to show that the editors of Lotus: AfroAsian Writings and some of the writers who contributed to it (especially

Afro-Asian internationalism

Bandung

Lotus

modernity

philosophy and theory of culture Ismail Ezzedine, Anar Rzayev, Tawfick Zeyad, Abdel Aziz El-Abwani, Joseph Ki-Zerbo, Alex La Guma, Adonis, Salah Dehni, Luis Bernardo Honwana, Ghassan Kanafany, and Tozaburo Ono) attempted to reconceive of nationalism in a way that would make international solidarity constitutive of the new national projects. It is argued that this is quite different from thinking of the contributors to Lotus as abandoning nationalism in favor of a supranationalist project. The second aim is to show that at least some of the contributors to Lotus thought of themselves as being the vanguard of modernity, and not as the creators of "alternative modernities". This essay shows that some of the aforementioned contributors to Lotus implicitly drew on standpoint epistemology in order to argue that, due to their struggles against colonialism, racial discrimination, etc., they had a privileged epistemic vantage point from which to criticize modernity in its European form for not being modern enough.
\end{abstract}

Routledge Taylor \& Francis Group interventions, 2020

https://doi.org/10.1080/1369801X.2020.1784021

Zeyad el Nabolsy ze44@cornell.edu

(C) 2020 Informa UK Limited, trading as Taylor \& Francis Group 


\section{Introduction}

1 Lotus essentially did not publish on Chinese related topics. The SinoSoviet split clearly influenced the purview of Lotus. 2 In many respects the Cairo-based Permanent Bureau was able to have a significant influence on the nature of the cultural material circulated in the Soviet Union from the 1970s onwards; Soviet publishing houses were putting out hundreds of titles by Afro-Asian writers (Yashen 1971).
The Afro-Asian Writers' Bureau (AAWB) was a product of the Afro-Asian Peoples' Solidarity organization, which was established following the first Afro-Asian Peoples' Solidarity conference in Cairo (26 December 1957-1 January 1958). The AAWB was intended to serve as the cultural arm of the alliance of the formerly colonized peoples which was initiated in Bandung in 1955. It was the institutional embodiment of the demand for cultural cooperation between the peoples of the Third World which was brought forward in the final communique of the Asian-African conference at Bandung: "The Asian-African conference was convinced that among the most powerful means of promoting understanding among nations is the development of cultural cooperation ... The peoples of Asia and Africa are now animated by a keen and sincere desire to renew their old cultural contacts and develop new ones in the context of the modern world" (Asian-African Conference 2009, 97). The Afro-Asian Writers' Bureau split in 1966 into the Cairo-based Permanent Bureau of Afro-Asian Writers and the Beijingbased AAWB (Yoon 2015).

The Beijing-based AAWB would publish the periodical The Call, which was discontinued during the later period of the Cultural Revolution in China. ${ }^{1}$ The Cairo-based Permanent Bureau published the periodical Lotus: Afro-Asian Writings, which circulated from 1968 until it ceased publication in the early 1990s with the collapse of the USSR and the GDR, who along with Egypt, provided its main source of funding (Halim 2012). ${ }^{2}$ Hala Halim has argued that Lotus was the locus of an attempt to create an anti-Eurocentric literary culture based on South-to-South networks of cultural, political, social, and economic solidarity (Halim 2012). In this essay I build on Halim's work, but I do not aim at providing an account of Lotus in terms of tracing an alternative comparatist line of descent as she attempts to do (Halim 2012, 565). Instead, I strive to show that the editors of Lotus and some of the writers who contributed to it (especially Ismail Ezzedine, Anar Rzayev, Tawfick Zeyad, Abdel Aziz El-Ahwani, Joseph Ki-Zerbo, Alex La Guma, Adonis, Salah Dehni, Luis Bernardo Honwana, Ghassan Kanafany, and Tozaburo Ono) sought to reconceive of nationalism in a way that would make international solidarity constitutive of the new national projects. In this respect, my approach is quite different from Halim's approach, which argues that Lotus' project was a supranationalist/internationalist one in contradistinction to being one based on nation-states (Halim 2012, 556). What is at stake here is the extent to which the concept of the nation-state adopted by European states in the nineteenth century is to be considered as the concept of nationalism, as opposed to merely being one concept of nationalism amongst other possible conceptual approaches to nationalism. In other words, I do not think of Lotus as a cultural project as involving the abandoning of 
nationalism; instead, I argue that it is based on a reconceptualization of nationalism. Moreover, I argue that at least some of the contributors to Lotus thought of themselves as being the vanguard of modernity. I contend that their commitment to modernity as an approach to understanding history is evidenced by the manner in which they conceived of their relations to their traditions. Specifically, I show that they consciously thought of themselves as the vanguard of modernity insofar as they thought of themselves as advancing the most well-developed version of modernity. In this respect I am building on Duncan M. Yoon's (2015) work. Yoon argues the Afro-Asian Writers' Bureau's cultural project was based on advancing a specific concept of history (although Yoon is primarily interested in the Beijingbased Afro-Asian Writers' Bureau). I contend that they were advancing a modern or modernist concept of history. However, unlike Yoon, I do not argue that the approach of the Afro-Asian writers whose work I will be examining below can be subsumed under the concept of "alternative modernity" (Yoon 2015, 245). Instead, they implicitly drew on the standpoint epistemology that is associated with Marxism as a theoretical framework in order to argue that due to their struggles against colonialism, racial discrimination, etc., they had a privileged epistemic vantage point from which to criticize modernity in its European form for not being modern enough, and that the fact that they have endured colonialism, racial discrimination, etc., means that they have a more refined understanding of the basic postulates of modernity, e.g. autonomy, the centrality of reason as source of normative justification, etc. I examine some of the aspects of Lotus that are not examined by Halim in her article. Halim notes that some of the writers who contributed to Lotus were drawn to Marxism; however, she does not discuss how they drew on the theoretical resources of Marxism in order to further develop their own cultural projects (Halim 2012, 571).

In this respect, this essay illustrates the manner in which Marxism was an important theoretical resource for some of the writers of Lotus. In this context, we should think of the engagement of anticolonial thought with Marxism as part of the project of creating what Siba Grovogui has called a new "moral space" that would reflect the needs of the Third World and that would point towards the epistemic gains of the anticolonial struggles (Grovogui 2016, 124).

\section{Bandung-style nationalism and internationalist solidarity}

The editors of Lotus conceived of their task as being essentially political in nature. Lotus was to serve as an outlet for national authors for whom internationalist solidarity was constitutive of the national character of their literary 
3 Whenever I have been able to locate Arabic issues of Lotus, I have translated directly from the Arabic version of the article (if the article was originally written in Arabic). However, I frequently had to resort to the English translations of the published issues due to an inability to locate the corresponding Arabic issues.

4 For an analysis of the Egyptian Nasserist project from this perspective, see Salem (2018). works. The spirit of internationalism and more specifically the quest for a model of nationalism and national culture that would reject the European construction of nationalism and national culture permeated the pages of Lotus. The following statement issued at the tenth session of the Afro-Asian Writers' Permanent Bureau (held in Cairo on 5-6 January 1973) is typical of the spirit which animated the editors of Lotus: "we the Afro-Asian writers, meeting in Cairo for the tenth session of the Permanent Bureau of our association, wish to reassert our boundless solidarity with the peoples engaged in a glorious and relentless struggle against imperialism, neocolonialism, racial discrimination and against the violation of the rights of man" (El Sebai 1973, 201). ${ }^{3}$ In Lotus there was a project to rethink the relationship between national culture and internationalism; there was an attempt to make internationalist solidarity a constitutive component of national identity (and therefore a constitutive component of the consciousness of the AfroAsian individual qua writer, artist, poet, and philosopher). There is a very significant difference between the conceptions of nationalism and national culture that are found in the pages of Lotus and the conceptions of nationalism and national culture that emerged from the European national movements of the nineteenth century. For the latter, nationhood and national culture are defined in exclusionary terms, and the essential characteristics of a given national culture can and should be specified without positing relations of solidarity to that which is considered to be outside the nation. In fact, as Sandra Halperin points out, nationalism as it developed in its nineteenthcentury European form was based on "an image of the world as consisting of racially homogeneous societies locked into relations of antagonism with other racially homogeneous societies" (Halperin 2013, 113). It would be incorrect to say that this conception of nationalism did not involve positing any essential relation to the other, for in fact it relied on positing an antagonistic relation to the other that was essential insofar as it was a constitutive condition of the nation's being and of the belonging of individuals to the nation. While one can characterize the projects of the Bandung states as nationalist, it would be too simplistic to think that they merely sought to re-create the nationalist projects that were associated with European nationalism in the age of imperialism. Siba Grovogui has argued that without recognizing the novelty of the projects that the nationalist leaders of the Third World engaged in, one cannot understand the significance of Bandung and its effects on the world (Grovogui 2011). ${ }^{4}$ Grovogui argues that the leaders of the Bandung project aspired to a different kind of universalism. I am making a structurally analogous argument to the effect that some of the contributors to Lotus, acting (at least in part) as the cultural arm of the Bandung project, aspired to a different kind of nationalism.

In opposition to the nineteenth-century European conception of the nation and national culture, the conception of nationhood and national culture that 
5 An accidental property of a thing is a property that a thing has but need not have in order to be the thing that it is. See the overview in Robertson and Atkins (2016). was being developed and enacted in the pages of Lotus was based on the characterization of internationalist solidarity as a necessary condition for belonging to the nation. On this view, to be a Palestinian, an Indonesian, or an Angolan was to express internationalist solidarity with all of the oppressed peoples of the world, and to act on this expression in concrete political and social terms. In other words, the identity conditions for being a Palestinian, for example, included being an internationalist. What is significant here is that internationalism is not conceived of as existing in an antithetical relation to nationalism. Internationalist solidarity is not understood in terms of a demand to transcend the nation; rather, it is a requirement for being more firmly rooted in it. For instance, in 1972 the Azerbaijani writer Anar Rzayev argued that any given literature must be a national literature insofar as it draws sustenance from the concrete historical reality of a given people, but this in no way precludes deep influences from the literature of other nations. However, he also argues that the writer should not consciously attempt to display the nationalist credentials of his or her work: "A true artist does not feel the need to express national affiliation with the aid of superficial signs of 'local colour'; it is something he does intuitively as the only possible expression of his talent (Anar 1972, 33)." Youssef El Sebai, who served as editor of Lotus until his assassination in 1978, in the context of discussing Arabic literature also emphasized the importance of recognizing the specificities of each Arab country, and the importance of recognizing how those specificities informed the development of national cultures in the Arabic-speaking world. However, this recognition did not prevent him from arguing that "culture does not know frontiers, that is why we [in Egypt] eagerly welcome the cultural trends from all parts of the world" (El Sebai 1976b, 7).

According to the conception of nationalism propagated by some of the authors who contributed to Lotus, if you failed to be an internationalist in outlook and conduct, then you failed to be Palestinian (for example) in the proper sense. Internationalist solidarity with other peoples of the Third World was not to be considered an accidental (in the technical philosophical sense) characteristic which one had. ${ }^{5}$ Rather, it was an essential characteristic which one had to possess in order to belong to the nation. A Palestinian poet expressing solidarity in his poems with the Angolan struggle for independence was not to be described as just a Palestinian who happened to stand in solidarity with the Angolan people, but rather as a poet who stood in solidarity with the Angolan people precisely because he was Palestinian, and particularly because if he did not do so he would not be considered Palestinian. Here we have a conception of national identity according to which the relation to the other is internal and constitutive of that identity.

The emotional ties that were sought after here are not to be described in terms of the concept of sympathy. For as the Egyptian writer Ismail Ezzedine 
noted, sympathy "may take place in the form of a passing emotional reaction which may last for a moment without implying lasting involvement in the cares of the other party" (Ezzedine 1974, 43). Sympathy, as Ezzedine understands it, is the kind of emotional tie that the spectator has with a character in a dramatic performance. In other words, it is an emotional tie that a passive observer has with the subject of a series of actions. However, as Ezzedine emphasizes, the internationalist solidarity that the writers around Lotus attempted to develop and defend was not adequately described in terms of an emotion that a spectator would feel towards a performance in which she takes no part. Afro-Asian writers had to identify with other peoples, literally to think of themselves as part of a whole in relation to them:

The Afro-Asian writer is by no means a spectator, either with regard to his own people or the peoples of the two continents. He is bound to his people with the ties which bind a citizen to his nationality and, at the same time, he is bound to all the peoples of the two continents with a bond of the same nature. (Ezzedine 1974, 43)

The key point is that, ideally, the Afro-Asian writer would experience a sense of identity with other oppressed peoples, and that this sense of identity would be different from the sympathy that would be experienced by somebody who looks favorably upon the struggles that are waged by the peoples of the Third World but who does not actively partake in those struggles.

This distinction between identification and sympathy is then employed by Ezzedine to differentiate between western voices that speak out in support of anticolonial struggles and the voices of the writers of the Third World who speak out in support of anticolonial struggles that are being waged by other peoples of the Third World:

These voices [of western supporters], which are few in number, but not devoid of faithfulness, that take our side at times and champion the just causes of man in the two continents, are, undoubtedly, the voices of sympathizers. We should be grateful to them for their sympathy, for they cannot, in all fairness, be expected to consider those causes as their own, as they are not personally involved in any of them. (Ezzedine 1974, 43)

One should not think that Ezzedine is here being exclusionary for the sake of "getting back at the Europeans." Rather, his claim is to be understood in relation to his historical materialist orientation towards social and psychological analysis. In other words, he is simply pointing out that the social conditions under which an author lives and in relation to which she forms her orientation towards the world constrain her psychological orientation and the emotional relations that she has with events in the world. The AfroAsian writer, unlike the western writer in the metropolis, living in a social 
environment that is dominated by anticolonial and anti-racist struggles, feels that she is a part of those struggles - she has no other choice (except perhaps to escape into the realm of self-deceptive aestheticism). Ezzedine is here clearly talking about westerners who are living in the metropolis, and not about westerners who took part in the armed struggles against colonialism. He is not, for example, talking about the French leftists who fought with the Algerians in the Algerian War of Independence (Fanon 1967, 147-178).

The Afro-Asian writers attempted to construct a national cultual tradition constituted by international solidarity based on the constraints imposed locally by the given social reality and globally by the given geopolitical situation. More important is the fact that the national tradition which is being constructed here (and it is important to note that the writers around Lotus were aware that traditions are invented and that they were in the process of inventing a new tradition of internationalist solidarity) is essentially characterized by solidarity with the struggles of other oppressed peoples. This is explicit in Ezzedine's writings: “Afro-Asianism has become, for him [the Afro-Asian writer], a wider and more comprehensive nationality" (1974, 43).This represents a remarkable departure from European conceptions of nationalism and national culture, and it constituted the norm through which national cultural productions were articulated for at least some of the writers who contributed to Lotus. Consequently, when Tawfick Zeyad attempts to describe the national character of Palestinian poetry, he emphasizes its internationalist nature:

We have sung poetry that came from the heart, full of love and faith in the struggle of all people, from those of Iran who nationalized its oil, to those of Cuba when it drove back the rampaging pigs from the 'bay of pigs'; from the people of Korea to the people of Lumumba's Congo and the small Vietnamese people whose land has become one big cemetery for the American invaders. We have sung for the negroes [sic] of America, Angola, and other lands. We have sung for the peoples whose revolutionary struggle against colonialism and for social liberation shaped our contemporary historical phase and has been an unbreakable support for our people's struggle. (Zeyad 1972, 45)

We can see that, for Zeyad, to be a Palestinian national poet, to be a poet of national resistance and of revolution is also to partake in internationalist solidarity, and to wield one's poetry as a weapon in the global struggle for emancipation. The internationalist character of Palestinian poetry was not just the expression of some kind of wishful idealistic orientation without any basis in material conditions. Zeyad emphasizes that the Israeli occupiers wanted to isolate Palestinians from the rest of the world, both culturally and politically: "the rulers of Israel, in their attempt to infuse despair into the hearts of our people and make them submissive and acquiescent to their policy, wanted 
to isolate it, not only from other Arab peoples, but also from other peoples of the world" (Zeyad 1972, 44). Consequently, internationalist solidarity and its expression in the literature of resistance, and the poetry of resistance in particular, was a necessary condition for undermining the Israeli policies which aimed to isolate the Palestinian cause in order to ensure that the Palestinians would be weakened in relation to their occupiers. Zeyad clearly identifies the way in which this isolation was promoted on a cultural plane by the Israeli occupiers through the encouragement of "indigenous" chauvinistic expressions of cultural identity: "they nurtured and encouraged the narrowmindedness of chauvinistic thought which does not extend beyond the hateful boundaries of fanatical tribalism" (Zeyad 1972, 44). Hence, we see that the struggle for a national culture within which internationalist solidarity was to be a constitutive element was waged against the attempt to encourage an isolationist, chauvinistic conception of national cultural identity which was in fact explicitly adopted by the colonizers as a cultural policy. Intellectuals in this context had to understand that their task was to create a culture that broke out of the prison of sterile insularity that was being constructed by the occupiers.

We see a global pattern of attempts by colonizers to isolate the colonized and to direct their intellectual energies towards a narrow, exclusionary conception of cultural identity. As Abdel-Aziz El-Ahwani argued, colonialism "obstructed all attempts at modernization and enlightenment while supporting reactionary tendencies whenever possible" (El-Ahwani 1970, 33). What is important about El-Ahwani's claim is that he makes a significant conceptual distinction between modernity (and enlightenment) and colonialism. In fact, he criticizes colonialism for obstructing all attempts at enlightenment. The accuracy of this claim is not significant for my argument. What I am interested in is the manner in which he criticizes colonialism from the standpoint of modernity. In other words, El-Ahwani seems to subscribe to what the Nigerian philosopher Olúfémi Táíwò has identified as the principles of modernity as a philosophical orientation: the commitment to the principle of autonomy, centrality of reason, and the belief in progress as a normative ideal (Táíwò 2010, 78-81). El-Ahwani self-consciously positions himself (and some of the other writers who contributed to Lotus) as the torch-bearer of the enlightenment, and he positions the colonialists as reactionaries who carry the banner of counter-enlightenment. In other words, he de-associates the concept of "modernity" from the concept of "the West", and he de-associates modernity from the phenomenon of colonialism. He presents colonialism as a movement that is incompatible with modernity and enlightenment. For while one can concede that the modernist philosophical orientation originated with the development of capitalism and colonialism, this is not logically incompatible with the claim that actualization of the normative principles of modernity as a philosophical orientation requires the overcoming of both capitalism and 
6 Nonetheless, one must concur with Halim's judgment that explicit references to Fanon are relatively rare in the pages of Lotus (Halim 2012, 580). Aside from the two references which Halim has uncovered, I have only been able to find references to Fanon's work in Joseph Ki-Zerbo's article. This is a phenomenon that requires explanation, but that is beyond the scope of my discussion.

\section{Amin is not} claiming that prior to modernity people did not make their own history. He is only claiming that prior to modernity people did not consciously think of themselves as makers of their own history: "This [the belief that humans are makers of their own history] marks a break with the dominant philosophy of all previous colonialism (and neocolonialism). This was an attitude that was also shared by the Burkinabé thinker Joseph Ki-Zerbo, who explicitly drew on Césaire in order to argue that modernity in its western guise, insofar as it was implicated in colonialism and racism, was a stunted, underdeveloped modernity. He draws on Césaire's critique, in his Discourse on Colonialism (Césaire 2001), of the pseudo-universalism and the pseudo-humanism which underlay western imperialism and colonialism in order to argue that the task of Africans is to create "a neo-African" culture that is more faithful to the principles of modernity than that which has come before it (Ki-Zerbo 1973, 156-157). In this respect, Ki-Zerbo also draws on Fanon's call in the The Wretched of the Earth: "we must make a new start, develop a new way of thinking, and endeavor to create a new man" (Fanon 2004, 239). ${ }^{6}$

Siba Grovogui points out that the Bandung project was in part motivated by the "realization, or consciousness, and judgement that Western imperialism had been falsely predicated upon modern, humanist underpinnings" (Grovogui 2016, 116). Hence, if we keep in mind that in many respects Lotus represented the cultural arm of Bandung, it is no surprise that some of the contributors to Lotus also held this view. This is significant insofar as it shows it is not necessary to impute to the writers I examine in this essay the belief that they were creating "alternative modernities". To explain what they said it is sufficient to impute to them the belief that they were the torch-bearers of modernity (without qualifiers), a modernity that was abandoned by those who participated in the colonialist projects, and those who defended those colonialist projects. In fact, insofar as the anticolonial movements drew on the principle of autonomy in order to argue for their right to self-determination, they were arguing for independence from within the framework of the philosophical discourse of modernity. Embracing modernity with its emphasis on autonomy means adopting a specific attitude towards history: it means that one comes to view human beings as the makers of their own history (Amin 2009, 13-14). ${ }^{7}$ As we will see below when we come to discuss the conception of cultural traditions that was endorsed by some of the writers who contributed to Lotus, this concept of history also implies that humans are makers of their own cultural identity, insofar as their cultural identity is a function of their history.

The policy of cultural and political isolation discussed above was also employed by the Apartheid regime in South Africa and in Rhodesia, as well as by the Portuguese in their African colonies (Davidson 1984). The internationalist solidarity which existed between Arabs, especially Palestinians, and Black African peoples engaged in revolutionary struggles for independence had both a humanistic philosophical motivation in the attempt to create a new, more universal humanism (although this was to be a universal humanism which did not submerge differences so much as integrate them) and the sociopolitical reality of the fact of the existence of alliances between the 
societies, both in Europe and elsewhere, based on the principle that God, having created the universe and mankind, is the 'legislator' of last resort” $(2009,13)$.

The same point is also made by Quijano (2000, 547).

8 After the 1973 war, most African countries severed ties with Israel (Oded 2010). This was quite a significant development given that in the 1960 s Israel had diplomatic relations with almost all of the independent African countries. In 1967 Guinea

(Conakry) became the first non-Arab African country to sever diplomatic ties with Israel.

9 For an account of the military assistance offered by Apartheid South Africa to the

Portuguese in

Mozambique, and of Israeli military support for Apartheid South Africa, see Husain (1982).

10 In his report on the Bandung Conference, Wright states that if "the men of the West were political animals, then the men of the East were religious animals" (2008, 491). Hence, Wright ascribed a unity to the peoples of Africa and Asia, but it was based on the idea that they colonizers. For instance, Israel was providing direct material support for several colonial governments in their fight against independence movements. As Youssef El Sebbai pointed out in 1974, "Israel provides the racist South African government, the racist regime in Zimbabwe and the Portuguese colonialists with the light weapons needed against African militants in the occupied areas" (El Sebai 1974, 10). ${ }^{8}$ Consequently, the internationalist solidarity which existed between, for example, Angolans and Palestinians had a very real material basis in the conditions of their respective struggles against their colonizers. ${ }^{9}$ Their colonizers supported each other, and it was only possible to triumph in their respective struggles by supporting one another. In other words, from a geopolitical standpoint there was no alternative to internationalist solidarity and the forging of an axis of solidarity along the political, economic, social, and cultural planes (Grovogui 2016, 119). What united the writers under discussion here was a deep understanding of this fact. The unity implied by the expression "Afro-Asian literature" was not a unity based on any kind of ethnic affinities (even mythologized ones). Nor was it based on a culturalist essentialism which grouped all nonwestern peoples together by characterizing them as essentially "spiritual" or "religious", as Richard Wright did when he reported on Bandung. Rather, it was based on the common struggle which the peoples of both continents undertook to liberate themselves from what Ismail Ezzedine called their "long night of colonialism" $(1974,40) .{ }^{10}$ In other words, it was essentially political in nature. In this sense it was an elaboration on the foundation of unity as described by Sukarno at Bandung: "we are united by a common detestation of colonialism in whatever form it appears. We are united by a common detestation of racialism. And we are united by a common determination to preserve and stabilize peace in the world" $(2007,235)$. As Hala Halim points out, there were also other more essentialist characterizations of the unity that is presupposed by the concept of "Afro-Asianess" (2012, 580). Halim points to such constructs as the "Afro-Asian personality" posited by the Egyptian philosopher Zaki Naguib Mahmoud. There are also occasional references to an "oriental mentality" (Hussein 1975, 52). Consequently, one cannot say there was a unified approach in the pages of Lotus in relation to the question of how to characterize Afro-Asian unity. I am only arguing that the writers whose work I am discussing in this essay adopted an anti-essentialist conception of the grounds of Afro-Asian unity. I argue this is a direct consequence of their adoption of a modernist concept of history, according to which humans are the makers of their own history and makers of their own cultural identity insofar as cultural identity is a function of history. For example, the Syrian poet Ali Ahmad Said Esber, better known as Adonis, argued that "the essence of man is that he is a creative being who can bring about change, and the essence of culture, consequently, is changing, creating" (Adonis 1975, 74). While it may appear strange to refer 
were all dominated by a specific kind of religiosity that obliterated all other aspects of cultural and social life: "a passionate unyielding religion, feeding on itself, sufficient unto itself" (489).

Contrary to what

Wright asserts, the unity among the formerly colonized peoples as it manifested itself in the Third World as a project was essentially political (Prashad 2007, 34). to what Adonis is expressing in this passage as an anti-essentialist conception of humans and of culture given his description of both in terms of "essences", it is nonetheless true that what he is claiming is that humans have, to some significant degree, the capacity to make themselves and to make their cultures. This characterization of human beings as having no fixed place and as capable of making and remaking themselves is a hallmark of modern humanist thought. We observe this characterization of human beings in Giovanni Pico della Mirandola's Oration on the Dignity of Man: "He [God] took up man, a work of indeterminate form; and placing him at the midpoint of the world, He spoke to him as follows: 'we have given to thee, Adam, no fixed seat, no form of thy very own, no gift peculiarly thine ... Thou, like a judge appointed for being honorable, art the molder and maker of thyself'" (Pico della Mirandola 2001, 4-5).

Another contributor to Lotus, the Syrian writer Salah Dehni, also adhered to this point of view (Dehni 1974, 164). From the standpoint of Adonis and Dehni, it does not make sense to impute to people anything like an unchanging "Oriental sensibility" or "African mentality", or something else along the same lines. I argue that the more ideologically coherent contributors to Lotus did not conceive of their unity in ethnic and racial terms but, rather, conceived of it in political terms (and in epistemic terms, as we will see below). Joseph Ki-Zerbo (1973), for example, emphasized cultural differences across the Afro-Asian world and across the African continent in particular. He argued that unity cannot be sought on cultural or ethnic grounds. It must be sought on political grounds, i.e. the commitment to a more just global order.

The identification of the Afro-Asian writer with the struggles of other peoples from the Third World was not contrived, nor can we say that it was the product of affectation. When the Indian poet Sajjad Zaheer expressed his bitterness about the devastating effects of the invasions of the Third World, he was not writing about India, but rather about Vietnam, and yet it is clear that this is a poem of a writer who experiences agony because of the devastation of a place that he identifies as home:

Accursed militarists' feet

Coming from thousands of miles away

Have snatched

Laughter from children

Smiles from the faces of mothers

And happiness from all

And have poisoned the very stream of life

(Zaheer 1967, 3; quoted in Ezzedine 1974, 44)

The awareness of the existence of extensive networks of solidarity between the various peoples of the Third World made victory appear possible (and in fact 
actually made it possible). For given that you were aware that your oppressor, e.g. the apartheid regime in South Africa, was not fighting you alone, and that they had allies who supported them morally and materially, it was crucial that there be a network of support for the oppressed so that you would not feel as if you were completely isolated. El Sebbai argued that one of the tasks of art in the struggles of the peoples of the Third World was to help them overcome the despair which comes from the temporary setbacks suffered by the antiimperialist forces (El Sebai 1974). In the case of South Africa, we see that Alex La Guma responded to temporary despair among his people by reminding them that they were not fighting alone: "We are not fighting alone, but side by side with all the peoples that believe in the same ideals: the peoples of Vietnam, the Arab World, Latin America, and Asia. We are aware that through our efforts, the solidarity of emancipated governments, socialist society and all the progressive and human forces, we shall triumph" (La Guma 1971, 197). The importance of the existence of such networks of solidarity which could be made salient in popular consciousness through the work of the Afro-Asian writer cannot be underestimated. Without such networks of solidarity, defeatism would have easily set in. Hence, in this respect, Lotus played a significant role in the development of the alliance initiated at Bandung.

\section{Third world standpoint epistemology}

It would be a mistake to think that because of the generally optimistic tone struck by the authors who contributed to Lotus, they did not problematize their own theoretical standpoints, or that they did not criticize the ideological orientations of the existing postcolonial states. It would be a mistake to think that they did not attempt to grapple with the question of whether anything called "Afro-Asian literature" exists concretely. Ismail Ezzedine, to name just one author, extensively theorized about the nature of Afro-Asian literature, and the conditions for its possibility. He argued that because of their collective struggles against racist colonialism, the peoples of Afro-Asia have a deeper commitment to equality and justice and a deeper understanding of the ways in which they can be subverted, and of what needs to be done to institutionalize "human rights" to make them efficacious, than do Europeans (in general), and that this is reflected in the new humanism expressed in the works of Afro-Asian writers:

The Afro-Asian peoples' stand against racial discrimination is a general point and common point of departure for the literature of the two continents alongside its other starting points. It is self-evident that the writers of Asia and Africa are 
11 The similarity of their struggles could also often lead to stylistic similarities in the works of art they produced. For instance, Barry Feinberg points out that when he showed some South African poetry to a Palestinian poet (unnamed by him), the latter was struck by the stylistic similarities to the Palestinian poetry he was acquainted with (Feinberg 1974, 10). equipped (better than anyone else, no matter how liberal his beliefs may be) for this confrontation and the manifestation, in works of art, of this human tragedy, for it is they who have experienced first hand the burden of that type of discrimination and have witnessed its devastating effects on the various aspects of the lives of their peoples. (Ezzedine 1974, 45)

In other words, Ezzedine claims that the experience of Afro-Asian writers gives them a privileged epistemic standpoint (although this standpoint is achieved through political struggle, it is not just a perspective that they have in virtue of their social position) in relation to the understanding of racism and colonialism, specifically their causes and their effects on their victims, and in relation to how best to combat them. ${ }^{11}$ Afro-Asian literature is in part made possible qua a concrete unity because its writers and artists work from a common epistemological standpoint, which was attained through struggle against racism and colonialism, and which gives them a privileged (in comparison to other writers, especially European writers) understanding of racism and colonialism. Ezzedine has here essentially produced a variant of standpoint epistemology almost ten years before Nancy C. M. Hartsock did (who is usually credited with the formulation of standpoint epistemology, specifically feminist standpoint epistemology, in North American academia). Hartsock's key insight is that "like the lives of proletarians according to Marxian theory, women's lives make available a particular and privileged vantage point on male supremacy, a vantage point which can ground a powerful critique of the phallocratic institutions and ideology which constitute the capitalist form of patriarchy" (Hartsock 1983, 284). Hartsock argues this privileged epistemic standpoint is achieved as a result of collective struggle; it is not merely given as a result of one's social position (285). The essential point is that the proponents of standpoint epistemology advance the thesis that in order to survive in social environments where one is oppressed, one must understand the systematic mechanisms that sustain oppression, and this involves understanding both the world of the oppressed and the world of the oppressor (Bowell 2011). Ezzedine had already recognized, almost ten years before Hartsock, that Marxist theory could be employed creatively in order to make a similar claim about the epistemic vantage point afforded to those who have experienced racism and colonialism and have struggled against them. Consequently, we can see that Lotus, in addition to being the site of literary innovations, was also the site of philosophical innovations (innovations which have, by the way, been ignored in contemporary Anglophone philosophy in North America and Europe). Robert J. C. Young has argued that Marxism has historically represented "the fundamental framework of postcolonial thinking" $(2001,6)$. In the case of some of the writers who contributed to Lotus, Marxism allowed them to develop a justification for the claim that the legacy of colonialism and racism that they suffered 
12 Dehni $(1974,157)$ makes a similar point about the influence of the struggle against and fought against allowed them to attain a privileged epistemic standpoint as a result of their collective struggles. ${ }^{12}$

\section{The weaponization of culture}

colonialism and oppression on the development of the philosophical attitude (and implicitly the epistemic standpoint) of the Arab writer.

13 Although I use the word "European" in this context, AfroAsian writers recognized that Europe was not a monolith and there were regions counted as European but which were marginalized within Europe (El Sebai 1971).
Aside from the shared privileged epistemic standpoint of Afro-Asian writers that gives them the epistemic tools which make it possible for them to engage in a critique of racism and colonialism that is more efficacious than any critique that could be offered by European writers (no matter how sincere they are), Ezzedine identifies other characteristics which made it possible to speak of something called "Afro-Asian Literature", ${ }^{13}$ arguing that Afro-Asian writers have a common militant standpoint which manifests itself in their work, and which differentiates it from other literatures. The literature produced by them is

a militant literature and those engaged in it are, more often than not, creative artists and fighters on the battle-field at one and the same time. There is no doubt that a literature such as this, stemming from the battle-field as this one does, no matter whether such battles are of liberation or of reconstruction, would, of necessity, have its own distinctive vision and its own special flavor. (Ezzedine 1974, 45)

The issue of commitment was one of the central themes that animated the authors whose work was published in Lotus. It is crucial to recognize that the fact that literature and culture generally were assigned the roles of weapons of "enlightenment and vigilance" in a global struggle does not mean they were regarded as of lesser concern than armed struggle (El Sebai 1976a, 7). In its report for the tenth session of the Afro-Asian Writers' Permanent Bureau, the editorial bureau of Lotus made it clear that "the role of the writer and the intellectual in the struggle is as important as that of the armed militant" (El Sebai 1973, 202). The writers played a crucial role in the elevation of popular consciousness and the articulation of revolution as a possible, and indeed necessary, solution to the problems that stemmed from the colonial situation. Given their militant commitment, it is not surprising that some of the Afro-Asian writers whose work appeared in Lotus rejected aestheticism or the idea of art for art's sake. Luis B. Honwana's judgment is representative: "because we speak of a functional art, functional for life, and we don't recognize the validity of any purely aesthetical criterion of judgment" (Honwana 1971, 156). There was also an instrumentalization of literature. For example, Okotaka Ebale, a writer from the People's Republic of Congo (also known as Congo-Brazzaville), claimed that, given the ongoing struggle against neocolonialism, the main aim of literature should be to 
14 However, the historical-materialist orientation they adopted was not based on the thesis that there existed a kind of one-to-one correspondence between works of art and economic structures, i.e., that every work of art was a direct expression of the economic structure of society. For a detailed critique of "vulgar" versions of historicalmaterialist approaches to art and art history, see Shukri (1970).

15 The idea that the Marxist project is essentially the attempt to bring about a "dialectical" return to precapitalist social formations is not uncommon among some Marxists, specifically those who place emphasis on Marx's Ethnological Notebooks (e.g., Gailey 2006). wipe out "the most pernicious influence of bourgeois ideology" and that literature plays a "a leading role in the framework of the party propaganda" (referring to the National Movement of the Revolution) (Ebale 1977, 1112). The delegation of Iraq presented a paper that explicitly used military metaphors in describing literature: "literature has, in fact, played the part of heavy artillery in man's decisive battles" (Delegation of Iraq 1972, 170). The Zambian writer William Saidi also adhered to this view. The same holds true for the Tanzanian writer J. P. Mbonde (1974, 12), as well as Samuel O. Asein (1975).

Nevertheless, one should not think that this rejection of "art for art's sake" is an expression of a crude attitude towards art. Rather, it was based on a historical-materialist understanding of the relationship between art and social life. ${ }^{14}$ The Mozambican writer Luis Bernardo Honwana argued the complete separation of art from social life (and more specifically from the everyday life of the masses), which is a necessary condition for even contemplating the possibility of art for art's sake, is the product of the development of the capitalist world-system. Honwana does not deny that in socially stratified precapitalist societies, art might have been separated from the everyday life of most people, but he does think that in pre-capitalist social formations art was not separated in a structural sense from social life as such. Honwana sees the task of Afro-Asian writers as an attempt (part of a larger socioeconomic project) to reproduce the close connection between art and everyday life that existed in pre-capitalist social formations, but on a higher plane, i.e. while preserving some measure of negative freedom, and making art immanent in everyday life for all people, as opposed to exclusively for those belonging to privileged strata. ${ }^{15}$ Moreover, it is difficult to see what adhering to "art for art's sake" could mean if one's people were living in refugee camps or under occupation. Given the situation, it was clear to Afro-Asian writers that what was needed was what Hanafy Ibn Issa called a "literature of emergencies" $(1972,151)$. It is not my intention to defend this conception of art and literature; I aim only to present a charitable reconstruction of the considerations that led some of the contributors to Lotus to adopt this view.

To this end, it is important to historicize the Bandung project, and to historicize the role of Lotus as one of the cultural arms of the Bandung project. In fact, one of the contributors to Lotus, Mohamadou Kane, sought to historicize the instrumentalization of literature that was consciously adopted as a conceptual framework by some of the contributors to Lotus. He argued that in the context of anticolonial struggles and struggles against neocolonialism, there was no other choice but to instrumentalize literature and to mold it into a weapon in this struggle. However, he was also critical of the manner in which the instrumentalization or weaponization of literature has been, according to him, carried out in a manner that prevented literature from adopting a more future-oriented approach to the depiction of social realities 
and possibilities: "too concerned over the struggle against colonialism, our literature seems to have lost sight of the need to prepare for the future" (Kane 1973, 12). Kane's contribution is important as an example of auto-critique in Lotus. Writing in 1973, he argues that "the struggle against colonialism should now give precedence to the edification of the city of the future" (15). Kane's justification for this call for reorientation was based on the fact that by the early 1970s, colonialism had been overturned in most of the African countries as well as in most of the Asian countries (although in this contribution Kane was mostly interested in the African continent). Nonetheless, it is important to note that by the early 1970s, the Portuguese colonies in Africa had still not been liberated and the same was true in Palestine. Hence, if one takes Kane's historicizing approach, one should take this into consideration when assessing the instrumentalization of literature and art in the African countries occupied by Portugal and in Palestine during the 1970s, as well as in Apartheid South Africa.

The efficacy of Afro-Asian writers as poets in the trenches of the anticolonial, revolutionary forces was recognized by the colonial forces who, by trying to suppress all expressions of cultural resistance, made it clear that they considered writers to be as important as armed militants. Israel, for example, during the war of 1967, waged a sustained campaign against Palestinian intellectuals, treating them as individuals who were taking part in anticolonial struggles through their writings. Almost all of the major Palestinian writers were placed under arrest (Kanafany 1971, 155). In occupied Palestine, writers played a crucial role in preserving indigenous culture in the face of the onslaught directed against it by the Israeli authorities. The strategies employed by the occupying authorities were diverse. They ranged from preventing the setting up of Arab theatres, the destruction of libraries, making sure that newspapers published in Arabic were under the editorial control of agents of the Israeli state, to promoting the view that literary Arabic was a dead language. Israeli intellectuals like Israel Moshe Beemnth were complicit in the framing of a project which sought to eradicate indigenous culture and to replace it with an ersatz, fossilized pseudo-culture curated by colonial officers. Beemnth, along with other Israel intellectuals, urged the use of slang in Arabic writing, and he claimed that literary Arabic should be consigned to the dustbin of history (Kanafany 1971). According to Kanafany, an attempt to make Palestinians despise their own culture was engineered by allowing only for the publication of writings in Arabic that were so inane that Palestinians would want to distance themselves from the "culture" that produced such dross. Kanafany's view was also shared by the Sri Lankan writer Gunasena Vithana, who argued that "literature and art were used as a tool by the imperialists to achieve their own goals" $(1974,20)$. We can see that in such a context the role of the Afro-Asian writer was crucial to the survival of cultural traditions. 


\section{The modernist conception of tradition}

16 Goethe makes a similar point in the first part of Faust: "Was du ererbt von deinen Vätern hast, Erwirb es, um es zubesitzen" (1986, I, $682 / 3)$. The point is that one must labor in order to make one's inheritance one's own.

17 The view that the preservation of tradition is essentially a creative activity was also articulated by Ritkheou (1977) in relation to his own Chukchi culture.

18 This modernist approach to tradition is also evident in Cabral's work: "we want, therefore, to destroy everything that would be an obstacle to the
While some of the contributors to Lotus understood themselves as carrying the torch of modernity (as opposed to attempting to create alternative modernities), it is important to understand how they viewed their relationship to their traditions. I argue that they thought that a given cultural tradition can only be said to be living if it retains its dynamism and corresponds to the concrete emotional and intellectual needs of a given people confronting a specific social reality. Hence, the Afro-Asian writer could not defend cultural tradition without at the same time changing it and revolutionizing it so that it corresponded to the varying requirements of different stages of the liberation struggles. This point was made by the Japanese poet Tozaburo Ono in his writings on the relationship between the preservation of cultural heritage and ruptures with that heritage. Ono emphasized that to preserve tradition implies inheriting it, and this in turn implies taking an active, creative stance towards tradition. ${ }^{16}$ In other words, through the study of a specific national literature (Japanese national literature), he was able to argue for the claim that the preservation of tradition necessitates its constant renewal; it was a perpetual creative task (Ono 1974, 46). He expresses the modernist consciousness of the fact that all traditions were once the novel products of human ingenuity: "even the 'old and good' must have once been new and bad in the eyes of old ones" (46).

Ono articulated this view of what it means to preserve tradition from the standpoint of modern Japanese literature, but the very same view of the preservation of tradition as necessarily involving creativity was also articulated by Mohammed Zniber from a Moroccan standpoint. Zniber argued that all theorization about tradition and how best to preserve it must depart from the standpoint of the new humanism (whose vanguard were, according to Zniber and other contributors to Lotus, the Afro-Asian writers themselves). ${ }^{17}$ This humanism was new in the sense that it was committed to a modernity that was not disfigured and stunted by racism and colonialism, i.e. a modernity that that goes beyond the pseudo-universalism associated with modernity in its western guise (intertwined with colonialism and imperialism). According to this new humanism, "the decisive factor is man himself. We can simply state that tradition is and has always been there to serve man. The contrary is not true; Man was not created to serve tradition. If tradition is an obstacle which impedes the progress of man, it should be renounced" (Zniber 1972, 172). ${ }^{18}$ While it is true that this attitude is also characteristic of modernity in its guise as the European Enlightenment, in the colonial context the extension of the category "man" (or "human") was restricted, such that the colonized peoples did not have a relationship that was characterized by autonomy vis-à-vis their own traditions. As was noted above, in many instances, colonial authorities thwarted attempts by the colonized peoples to overturn or 
progress of our people, all relations that there are in our society (in Guinea and Cape Verde), be they against the progress of our people or against the liberty of our people”. $(2016,77)$ restructure their traditions. One can say that in the colonial context, humans were made to serve traditions insofar as the ossification of traditions was useful from the colonizer's perspective. Consequently, we can see that in Zniber's article the question of tradition is transformed into a political issue, for the grounds on which any element of tradition was to be preserved was its contribution to the struggle for emancipation. This ability to discriminate between desirable and undesirable elements of tradition (in relation to the struggle for emancipation) was crucial in a context dominated by colonial and neocolonial efforts to destroy the elements of tradition that could be transformed by the colonized into tools of resistance and by efforts to preserve and manipulate those aspects of cultural tradition that would hamper emancipatory struggles, and essentially turn the colonized into prisoners inside a prison whose structure they themselves have helped build. When Kanafany spoke of the "cultural battle front" he was not speaking metaphorically - this is in fact the only appropriate description of the cultural situation in a colonized country. In this situation it was only natural for Afro-Asian writers to view themselves as engaged in war that ranged over all aspects of culture: music, poetry, sculpture, painting, philosophy, literature, etc.

In fact, if we are to speak with accuracy of the weaponization of culture in the pages of Lotus, we must speak specifically of the transformation of culture into a weapon in the hands of the oppressed, for culture had already been weaponized by the colonizers to serve as a tool of oppression. Halim has pointed out that some of El Sebai's editorials for Lotus can be described as "set pieces of propaganda" (Halim 2012, 581). While this is true to some extent, we should recognize that insofar as some of the writings in Lotus can be described as propaganda pieces, it is more accurate to refer to them as "counter-propaganda pieces" in order to recognize that they were a response to the propaganda waged by colonialists and imperialists. Also, one should not underestimate the existence of critical currents in Lotus, i.e. auto-critiques of the Bandung project. For example, in Adonis' contribution discussed above, he criticizes the Arab governments for perpetuating relations of exploitation and he criticizes the intellectuals who uncritically support them: "this ideology [the ideology of the Arab governments] does not establish new conditions ... it only reproduces relations of exploitation which belong to the past" (Adonis 1975, 67). Ibrahim Harkat also implicitly criticized Pan-Arabism from a Maghrebian perspective, arguing implicitly that it led to alienation in the Maghreb insofar as it led to the erasure of the Maghreb's Berber/Amazigh heritage (Harkat 1977, 54). Iyengar (1972) brought to the fore the important role of African writers as critics of the postcolonial state in Africa and its ruling elites. Furthermore, contributors such as Shukri (1970) argued for the freedom of art and literature from within a Marxist framework. 
In the colonial context, it would be misguided to attempt to frame the issue in terms of whether, for instance, poetry should be weaponized, for it had already been weaponized by the colonizers. The real issue was for whose benefit it would be politicized and weaponized. Culture became a battlefield on which the colonizers attempted to either completely erase all aspects of indigenous culture or to turn cultural tradition into a living fossil that would impede the ability of the colonized to resist their colonizers. As Honwana put it in his analysis of the structure of Portuguese colonialism in Mozambique, culture was transformed into a weapon by the Portuguese in their attempt to eradicate all traces of indigenous culture. The purpose was to wage a war on the cultural plane in order to eradicate indigenous identity: "the essential feature of the colonization of a people is the destruction of their identity" (Honwana 1971, 148). The situation was similar in the Arab world, as described by Abdel-Aziz El-Ahwani:

In the beginning it [colonialism] imposed its language by force on the conquered countries, making it compulsory for all stages of education, whereas the national languages were brushed aside to a secondary status. This was done in Egypt and, more hideously, in the Western Arab countries. Schools were turned into incubators for low-grade officials and government clerks. Colonialism fought savagely against national culture, and created obstacles to impede the establishment of free universities where a new generation could rise. (El-Ahwani 1970, 30)

The response of the Afro-Asian writer to this attempt to extinguish indigenous culture should be seen as dynamic insofar as it evolves over time and insofar as it changes dramatically with the initiation of the phase of armed struggle against the colonizer. According to Honwana, in Mozambique, the first stage of the development of a poetry of resistance took the form of a kind of Négritude; an affirmation of the image which the Portuguese colonists had constructed of African cultures and societies. For instance, in Noemia de Sousa's poetry we find pride in the supposedly "barbaric" nature of Africans: "O my Africa, mysterious, natural! I cannot, I CANNOT deny the black blood, the barbaric blood which you passed on to me" (FRELIMO Executive Committee 1969, 21; quoted in Honwana 1971, 152). Here we have a direct response to the attempts of the Portuguese to make their colonial subjects despise themselves. On the other hand, as Honwana notes, this is a poetry of resistance, but it is not yet a poetry of revolution. For it is a poetry characterized by an unqualified affirmation of tradition. It is, as Honwana notes, the poetry of those who resisted but were not able to draw sustenance from the existence of a concrete revolutionary movement. When we speak of the weaponization of culture we are speaking of the existence of a dialectical relation between culture, in this example poetry, and revolutionary movements. National poets of resistance like Noémia de Sousa served revolutionary 
purposes, even if their poetry was not explicitly revolutionary, by raising political and national consciousness. In fact, poetry was crucial in the project of imagining (in Benedict Anderson's sense) a nation that could be called Mozambique (just as it was and is crucial to the existence of an imagined community that one can call Palestine). For instance, Craveirinha in his poem Hino à minha terra attempts to help his readers and listeners imagine that they are united, via an invisible bond, to other Mozambicans they have never met, and whom they will never meet. The aim was to create in the mind of all Mozambicans an image of what Anderson calls their "communion" $(2006,6)$. He does this by familiarizing his readers and listeners with the names that define Mozambique geographically. These names are meant to evoke home for them, even if they have never seen the places that they name, and never will:

... and I say Metengobalame and Macomia

and it is Metangobalame and burning word which the Negroes have invented.

... and I shout Inhamussua, Mutamba, Massangulo!!!

and I shout again Inhamussua, Mutamba, Massangulo

and other names of my country

flow sweet and proud in filial memory

and in precise pronunciation I unclothe their beauty

(FRELIMO Executive Committee 1969, 22; quoted in Honwana 1971, 154)

On the other hand, despite playing a crucial role in making revolution a possibility, this poetry had to remain abstract and utopian because there was no concrete armed struggle for it to draw inspiration from. Honwana argues that because there was no revolutionary movement which could by its practical nature show the way forward to poets and hence help them see a way beyond the colonial situation that does not just look back to the past, poetry in Mozambique before 1962 could only refuse the colonial present by looking back to the past (and drawing on an image of the past and of tradition that was constructed in many ways by the colonizers). Honwana argues that the initiation of the armed struggle against the Portuguese colonizers transformed Mozambican poetry insofar as poetry could now become more concrete, could draw from the actual conditions of armed struggle against the colonizers. We can think of armed struggle in this context as having actualized and realized poetry. The poetry of indignation of poets like Craveirinha, which seemed to express a very abstract wish when it was written, became almost literally descriptive of the situation when placed in the context of the armed struggle. Craveirinha's Grito Negro is an excellent example of this transformation: 
I am coal

And you wrench me brutally from the ground.

And make me your mine, boss!

I am coal

And you light me, boss

To serve you eternally as a moving force

But not eternally, boss.

I am coal

And I have to burn, yes

And burn everything with the force of my combustion.

I am coal

The exploitation burns me

Burns me alive like tar, my brother, Until you are no longer mine, boss.

I am coal

I have to burn

Burn everything with the fire of my combustion.

Yes!

I will be your coal, boss!

(Craveirinha 2011; quoted in Honwana 1971, 151)

Without doubt, this poem expresses the understanding that the colonial situation simply cannot go on. However, without the existence of a revolutionary movement, this realization only leads to an abstract wish and to escapism (Mammeri 1974). The burning fire which would destroy the social relations of domination and subordination remains metaphorical. However, after 1962, we find that the context has changed. This poem is now reprinted in 25 de Setembro, the periodical issued by FRELIMO, and in this context the fire is no longer metaphorical (FRELIMO Executive Committee 1969). As Honwana puts it, "the words become true in a literal sense: the African has become the fire which is burning his former master ... There is no metaphorical residue left between the fire of poetry and the fire of grenades and mortars used against the enemy" $(1971,155)$. The weaponization of culture is complete. In the pages of Lotus revolutionary poetry and revolutionary struggle are mutually constitutive. Poetry, even when it is not yet revolutionary, paves the way for a revolutionary culture when it is based on a clear grasp of the intolerable colonial situation and a rejection of it. It awakens popular consciousness even if, before a certain stage in the struggle, it cannot reject the colonial present except by embracing the precolonial past without qualifications or reservations. On the other hand, the development of an actual revolutionary struggle for liberation opens up new possibilities and realities, and perhaps most importantly new responsibilities, for the 
poet. In this more advanced stage of the struggle, the poet can reject the colonial present without embracing the past in an unqualified manner. The poet can reject the colonial present in the name of a future for new human beings and a new society. Poetry in this context saves the art forms of the past, but not as dead pieces to be exhibited in a metropolitan museum, but rather as living components of a culture defined by resistance, literally forged in the crucible of liberation struggles, and in doing so it changes tradition. Consequently, on the one hand, we have continuity with the past, and on the other hand, we have a rupture with the past. The relationship between the cultural past and the cultural present as understood by the contributors to Lotus is exemplified by Atubwidao in his poem É nosso dever:

Our ancestors serve as an example

We shall learn from them, Destroying old conceptions, Creating a new spirit of patriotism

(FRELIMO Department of Information 1969, 34; quoted in Honwana 1971, 160)

For Atubwidao, one learns from the past precisely in order to "destroy old conceptions". The past that is the object of admiration here is the living past, the past as created by those who attempted to solve their problems within the constraints imposed upon them by their situation. It is essentially a dynamic past, a past that one cannot get in touch with by moving backwards. It is a past that one can only get in touch with by moving forward, i.e. actualizing its projected trajectory. Moreover, it should be understood

19 See also Cabral's (1979) discussion and critique of this depiction of the colonized people in colonialist thought. that when Afro-Asian writers attempted to glorify their past, this was in order to counter the colonial myth that they were "peoples without history". ${ }^{19}$ The attempt to make the people of the Third World believe they had no culture or that whatever they had was worthless can be counted among the worst crimes of colonialism. It severely undermined and it continues to undermine attempts to resist colonial and neocolonial incursions. As Julius Nyerere put it, "of all the crimes of colonialism there is none worse than the attempt to make us believe we had no indigenous culture of our own; or that what we did have was worthless, something of which we should be ashamed, instead of a source of pride" (1967, 186; quoted in Mbonde 1974, 16). Consequently, it is understandable that many AfroAsian writers turned towards the past, though again it is necessary to emphasize that they did not stop there. 


\section{Conclusion}

The project of retrieving the past was not driven by chauvinistic impulses, but rather by the need to restore confidence among people whose belief in their own abilities as creators of culture had been undermined by colonialism. The point was to create (even if the language used was often one of preservation) a living tradition, which allows one to interact with other cultural traditions with confidence, as opposed to giving in to impulsive imitation. We should not think that a defense of certain aspects of tradition is incompatible with embracing modernity. For if modernity is constructed on the principle that "human beings, individually and collectively (i.e. societies) make their own history" (Amin 2009, 7), and if colonialism has attempted to portray the colonized as peoples who have never been active subjects of history, and consequently as people who cannot be modern because they lack the requisite cultural agency, we can understand how Afro-Asian writers turned to the past in order to show that the peoples of the Third World had already been active subjects of history. They turned to the past not as a gesture of rejection towards modernity, but as a necessary condition for entering into modernity as creators of history and culture (and by the very nature of its normative structure, one cannot "enter into modernity" except as a creative historical subject - a contributor to its constitutive elements). In fact, as we saw above, especially in Ezzedine's work, some contributors to Lotus represented themselves as being not only modern, but also as the vanguard of modernity. In this context, reflection on the past made it possible to take up the struggles of the present in the name of a future that would be created by modern, autonomous human beings. It enabled them to both discover and invent traditions of resistance. Reflecting on Lotus today helps us do the same. It enables us to say:

we have carried on the march,

But we have not begun anew

(Zeyad 1972, 39)

\section{Acknowledgments}

An early draft of this essay was presented at the Axis of Solidarity: Landmarks, Platforms, Futures conference in London. I am grateful for the feedback provided by the audience and the organizers; with special thanks to Salah M. Hassan for his generous engagement with this essay. I am also grateful for Siba Grovogui's guidance on how to think about and with Bandung, and the helpful comments provided by two anonymous reviewers for Interventions. 


\section{References}

Adonis. 1975. "Thoughts on the Problems of Poetic Expression and Communication in Arab Society." Lotus: Afro-Asian Writings 23: 62-78.

Amin, Samir. 2009. Eurocentrism: Modernity, Religion, and Democracy. A Critique of Eurocentrism and Culturalism. Translated by Russell Moore and James Membrez. New York: Monthly Review Press.

Anar 1972. "The Joy of Communication." Lotus: AfroAsian Writings 12: 30-33.

Anderson, Benedict. 2006. Imagined Communities: Reflections on the Origin and Spread of Nationalism. London: Verso.

Asein, Samuel O. 1975. "The Revolutionary Vision in Alex La Guma's Novels." Lotus: Afro-Asian Writings 24-25: 9-21.

Asian-African Conference. 2009. "Final Communiqué of the Asian-African Conference." Interventions 11 (1): 94-102.

Bowell, Tracy. 2011. "Feminist Standpoint Theory.” In Internet Encyclopedia of Philosophy, edited by James Fieser, and Bradley Dowden. https://www. iep.utm.edu/fem-stan/.

Cabral, Amílcar. 1979. "The Weapon of Theory." In Unity and Struggle: Speeches and Writings of Amilcar, translated by Michael Wolfers, 119-137. New York: Monthly Review Press.

Cabral, Amílcar. 2016. "Analysis of a Few Types of Resistance." In Resistance and Decolonization, translated by Dan Wood, 73-156. New York: Rowman \& Littlefield.

Césaire, Aimé. 2001. Discourse on Colonialism. Translated by Joan Pinkham. New York: Monthly Review Press.

Craveirinha, José. 2011. "Black Outcry.” In Stained Glass: Poetry From the Land of Mozambique, edited by Luis Rafael, translated by Luis Rafael and Stephen Gray, 51. Kolkata: ROMAN Books.

Davidson, Basil. 1984. "On Revolutionary Nationalism: The Legacy of Cabral." Latin American Perspectives 11 (2): 15-42.

Dehni, Salah. 1974. "The Double Function of Arabic Literature." Lotus: Afro-Asian Writings 22: 157165.

Delegation of Iraq. 1972. "Artistic Expression in the Battle for Existence." Lotus: Afro-Asian Writings 14: $170-178$.

Ebale, Okotaka. 1977. "The Anti-Imperialist Literature and the New Generations." Lotus: Afro-Asian Writings 31: 8-19.

El Sebai, Youssef. 1971. "6th Session of the Afro-Asian Writers' Permanent Bureau.” Lotus: Afro-Asian Writings 8: 195-202.
El Sebai, Youssef. 1973. "10th Session of the AfroAsian Writers' Permanent Bureau." Lotus: AfroAsian Writings 17: 195-202.

El Sebai, Youssef. 1974. "The Role of the Afro-Asian Writer in the Liberation Struggle." Lotus: AfroAsian Writings 20: 8-12.

El Sebai, Youssef. 1976a. "The Writer and Commitment.” Lotus: Afro-Asian Writings 29: 6-8.

El Sebai, Youssef. 1976b. "Thoughts on Some Aspects of Cultural Life in Egypt." Lotus: Afro-Asian Writings 30: 6-7.

El-Ahwani, Abdel-Aziz. 1970. "The Arab Intellectual and Neocolonialism." Lotus: Afro-Asian Writings 1: 27-35.

Ezzedine, Ismail. 1974. "Afro-Asian Literature: Its Nature and the Role it Plays Against Imperialist Aggression, Racial Discrimination and Zionism." Lotus: Afro-Asian Writings 20: 41-60.

Fanon, Frantz. 1967. A Dying Colonialism. Translated by Haakon Chevalier. New York: Grove Press.

Fanon, Frantz. 2004. The Wretched of the Earth. Translated by Richard Philcox. New York: Grove Press.

Feinberg, Barry. 1974. "Poetry and National Liberation in South Africa." Lotus: Afro-Asian Writings 22: 10 18.

FRELIMO Department of Information. 1969. "The Role of Poetry in the Mozambican Revolution." Mozambique Revolution 38: 15-33.

FRELIMO Executive Committee. 1969. "The Role of Poetry in the Mozambican Revolution." Africa Today 16 (2): 19-22.

Gailey, Christine W. 2006. "Community, State, and Questions of Social Evolution in Karl Marx's Ethnological Notebooks." In The Politics of Egalitarianism, edited by Jacqueline Solway, 31-52. New York: Berghahn Books.

Goethe, Johann Wolfgang. 1986. Faust. Der Tragödie / Erster Teil. Ditzingen: Reclam.

Grovogui, Siba N. 2011. "A Revolution Nonetheless: The Global South in the International." The Global South 5 (1): 175-190.

Grovogui, Siba N. 2016. "Remembering Bandung: When the Streams Crested, Tidal Waves Formed, and an Estuary Appeared." In Meanings of Bandung: Postcolonial Orders and Decolonial Visions, edited by Quỳnh N. Pham, and Robbie Shilliam, 115-132. New York: Rowman \& Littlefield.

Halim, Hala. 2012. "Lotus, the Afro-Asian Nexus, and Global South Comparatism." Comparative Studies of South Asia, Africa and the Middle East 32 (3): 563-583. 
Halperin, Sandra. 2013. Re-Envisioning Global Development: A Horizontal Perspective. New York: Routledge.

Harkat, Ibrahim. 1977. "Maghreb Culture among Human Cultures." Lotus: Afro-Asian Writings 31: 52-62.

Hartsock, Nancy C. M. 1983. "The Feminist Standpoint: Developing the Ground for a Specifically Feminist Historical Materialism." In Discovering Reality: Feminist Perspectives on Epistemology, Metaphysics, Methodology, and the Philosophy of Science, edited by Sandra Harding, and Merrill Hintikka, 283310. Dordrecht: D. Reidel.

Honwana, Luis B. 1971. "The Role of Poetry in the Mozambican Revolution." Lotus: Afro-Asian Writings 8: 148-166.

Husain, Azim. 1982. "The West, South Africa and Israel: A Strategic Triangle." Third World Quarterly 4 (1): 44-73.

Hussein, Taha. 1975. "Egypt and Cultural Exchange." Lotus: Afro-Asian Writings 24-25: 51-54.

Ibn Issa, Hanafy. 1972. "The Arab Writer: Between Two Worlds.” Lotus: Afro-Asian Writings 14: 149-153.

Iyengar, K. R. Shrinivasa. 1972. "The Tormented Tree: The Agony of the African Writer." Lotus: AfroAsian Writings 12: 10-21.

Kanafany, Ghassan. 1971. "The Cultural Situation of the Arabs in Occupied Palestine." Lotus: AfroAsian Writings 10: 148-164.

Kane, Mohamadou. 1973. "Francophonie et Spécificités Littéraires Africaines." Lotus: Afro-Asian Writings 17: 12-15.

Ki-Zerbo, Joseph. 1973. "Positions and Propositions for an African Neo-Culture." Lotus: Afro-Asian Writings 15: 148-157.

La Guma, Alex. 1971. "Address by Lotus Award Winner." Lotus: Afro-Asian Writings 10: 195-197.

Mammeri, Mouloud. 1974. "Popular Poetry and Resistance (An Algerian Poet)."Lotus: Afro-Asian Writings 20: 62-69.

Mbonde, J. P. 1974. "The Role of Literature in the Process of Tanzania's Development." Lotus: AfroAsian Writings 21: 10-18.

Nyerere, Julius. 1967. Freedom and Unity, Uburu na Umoja: A Selection From Writings and Speeches, 1952-65. Dar es Salaam: Oxford University Press.

Oded, Arye. 2010. “Africa in Israeli Foreign Policy Expectations and Disenchantment: Historical and Diplomatic Aspects." Israel Studies 15 (3): 121-142.

Ono, Tozaburo. 1974. "On Heritage and Discontinuity.” Lotus: Afro-Asian Writings 22: 44-49.

Pico della Mirandola, Giovanni. 2001. On the Dignity of Man. Translated by Charles Glenn Wallis, Paul
J. W. Miller, and Douglas Carmichael. Indianapolis: Hackett.

Prashad, Vijay. 2007. The Darker Nations: A People's History of the Third World. New York: New Press. Quijano, Anibal. 2000. "Coloniality of Power, Eurocentrism, and Latin America." Nepantla: Views From the South 1 (3): 533-580.

Ritkheou, Yuri. 1977. "Once Upon a Time: Oral Tradition and Modern Culture." Lotus: Afro-Asian Writings 31: 22-32.

Robertson, Teresa, and Philip Atkins. 2016. "Essential vs. Accidental Properties." In The Stanford Encyclopedia of Philosophy, edited by Edward $\mathrm{N}$ Zalta. https://plato.stanford.edu/archives/spr2018/entries/ essential-accidental/.

Salem, Sara. 2018. "Reading Egypt's Postcolonial State Through Frantz Fanon: Hegemony, Dependency and Development." Interventions: International Journal of Postcolonial Studies 20 (3): 428-445.

Shukri, Ghali. 1970. "Lenin, Literature and Art." Lotus: Afro-Asian Writings 6: 134-153.

Sukarno, Ahmed. 2007. "President Sukarno's Opening Speech, Afro-Asian Conference, Bandung, 18-24 April 1955." In The Political and Moral Imperatives of the Bandung Conference of 1955, edited by Kweku Ampiah, 233-240. Leiden: Brill.

Táíwò, Olúfémi. 2010. How Colonialism Preempted Modernity in Africa. Bloomington: Indiana University Press.

Vithana, Gunasena. 1974. "The Image of the New Man.” Lotus: Afro-Asian Writings 22: 20-24.

Wright, Richard. 2008. "The Color Curtain: A Report on the Bandung Conference." In Black Power, Three Books From Exile: Black Power; The Color Curtain; and White Man, Listen!, 433-609. New York: Harper Collins.

Yashen, Kamil. 1971. "Unity and Solidarity." Lotus: Afro-Asian Writings 9: 24-27.

Yoon, Duncan M. 2015. “'Our Forces Have Redoubled': World Literature, Postcolonialism, and the Afro-Asian Writers' Bureau." Cambridge Journal of Postcolonial Literary Inquiry 2 (2): 233-252.

Young, Robert J. C. 2001. Postcolonialism: An Historical Introduction. Oxford: Blackwell.

Zaheer, Sajjad. 1967. “"Tahiyya ila Fiyatnam” [Greetings to Vietnam]." Al-Ittihad June 23.

Zeyad, Tawfick. 1972. "Concerning Arabic-Palestinian Revolutionary Poetry.” Lotus: Afro-Asian Writings 12: 37-47.

Zniber, Mohammed. 1972. "Tradition and Innovation From Morocco." Lotus: Afro-Asian Writings 11: 172-173. 